ISSN: 2716-1277

e-ISSN: 2716-1269

Available online at TLIC https://jlic.iain-jember.ac.id/
Journal of Language Intelligence and Culture

Fakultas Tarbiyah dan Ilmu Keguruan

IAIN Jember

Vol. 3, No.2, Page 125-138, December 2021

\title{
Using Inquiry Based Learning to Improve Student's Speaking Skills
}

\author{
Suparwoto Sapto Wahono, \\ State Islamic University of Kiai Haji Achmad Siddiq Jember \\ Email:wahsapto@gmail.com \\ Ira Hamida Nurul Zahro, \\ State Islamic University of Kiai Haji Achmad Siddiq Jember
}

\section{ARTICLE INFO}

\section{Article History:}

Accepted: July 2021

Approved: December 2021

Published: December 2021

Key Words:

Inquiry-based learning,

speaking skills

DOI: $10.35719 / j l i c . v 3 i 2.55$

\begin{abstract}
English is one of the existing languages in this world.Speaking is one of the important skills in English. A priority for many second language or foreign language learners is the mastery of speaking. Speaking is one of the indicators that someone understands English. As a foreign language, English tends to be difficult to be learnt by foreign language learners. The researcher aimed to find out if the use of inquiry-based learning method can improve the students' speaking skill at the tenth-grade students of vocational high school. This research used classroom action research (CAR). The cycles of this research were planning, acting, observing, and reflecting. The method used in collecting the data was a test. The research result of students' pre test was 66.6. Meanwhile the students' post test result was 72.2. In conclusion inquiry based learning method improved speaking skill at the tenth grade students of vocational high school.
\end{abstract}

\section{INTRODUCTION}

Language is one of the main ways to connect with others. It is a vital or important tool to use in communication. It also cannot be separated from our lives because it is used to connect human social life. Language is a part of culture and also a part of human behavior. By using language, people are able to communicate and cooperate with others. It is also as a medium in expressing ideas, feeling, and thought. The purpose of real communication is to 


\section{JLIC}

accomplish a task, such as conveying news, obtaining information, or expressing opinion.

English is one of the existing languages in this world. Hammer (2001: 13) stated that English is a language which is used for International communication. As language for International communication, English is spoken by many people in the world as the second language, the third language or as a foreign language (Harmer, 2001). Wahono (2018: 98) stated that speaking is one of language skills which is a proof that someone understands English. Language can become a bridge to connect with each other, even in the same place or in different places. According to Wardhaugh (2006) in Wahono and Qodriah (2019: 593) stated that language is what the members of particular society speak. The important thing in the language is how people communicate using spoken or written the language to get information from other people.

In teaching speaking, teacher usually has some techniques or method. The techniques must be extremely interesting and fun. Teacher who can choose the best technique or method in teaching speaking can be implied to achieve the desire of the learning objectives. Kinsvatter (2996:258) stated that inquiry method is a generic term that applies to methods with which teachers engage students' critical thinking skills to analyze and solve problems in a systematic fashion."

\section{Speaking Skill}

Speaking and listening are the fundamental skills. Learning through speaking is natural way of learning a foreign language (Hussain, 2017). Richard (2002) said that speaking is the verbal use of language and a medium through which human beings communicate with each other. It means that speaking is a part of language that used as medium to communicate with others. It is the most demanding skill that people need to communicate in everyday situation. In the other word, speaking is also seen as an interactive process of constructing meaning that involves producing and receiving information in order to get particular end between speaker and listener.

According to oxford dictionary (2003), speaking is simply concerning putting ideas into words to make other people grasp the message that is conveyed. When people communicate with others, speaker will use some utterances in order to tell the purpose to the 
listener. The speaker should be able to transform their ideas into words in order to make sure the listener understands what they are talking about. Speaking is also depending on the speaking context. People learn language because they want to apply language in specific purpose (Harmer, 1991). For example, speaking between students is about situation at school, assignments, materials, score, etc. it will be different with speaking used by fisherman, they often speak about bats, weather and fish harvest among fisherman.

Therefore, speaking is the ability to express feeling, opinion, or information in order to communication with others in spoken language. There is an information gap between what speaker said and what listener received when they are talking, both of them should be able to comprehend the information given in order to achieve good communication.

\section{Types of Spoken Language}

Based on Brown (2003) there are two kinds of spoken language, they are monologue and dialogue.

1. Monologue

In monologues, when one speaker uses spoken language for any length of time, as in speeches, lectures, readings, news broadcasts, and the like, the hearer must process long stretches of speech without interruption. Monologues differ considerably in their discourse structures. To be able to do this, language learners should have sufficient knowledge of the sound, structure, vocabulary, cultural system of English language, think about the ideas they wish to express, have to be English sound well by changing the positions of lips, jaws, and tongue. Besides that, the learners should be consciously aware of the appropriate functional expression as well as grammatical, lexical and cultural features needed to express the idea, be sensitive to the change of register or style necessitated by the person to whom they speak and also the situation in which the conversation takes place and must have the abilities to change their direction of their thoughts on the basis of the persons' responses.

From the explanation above, monologue is one speaker that speaks to listener or spectator in length of time. The opportunities to interact from the listeners are limited, such as speeches, readings (the message from writer to reader), oral presentation, news broadcast, storytelling and etc. such us speeches, news broadcasts and etc. In addition, when speaker does not prepare before on his 


\section{JLIC}

or her speech, it is unplanned. But when speakers planned, they should have knowledge of the sound, structure, vocabulary, cultural system of English language, have to think about the ideas they wish to express, and have to be English sound well.

2. Dialogue

Dialogue is involved by two or more speakers and can be subdivided into interpersonal and transactional. The interpersonal is an exchange that promotes social relationships while transactional is the purpose to convey propositional or factual information. In each case, participants may have a good deal of shared knowledge (background information, schemata); therefore, the familiarity of the interlocutors will produce conversations with more assumptions, implications, and other meanings hidden between the lines. In conversations between or among participants who are unfamiliar with each other, references and meanings have to be made more explicitly to assure effective comprehension. When such references are not explicit, misunderstandings can easily happen.

Therefore, dialogue is not same with monologue; the speakers in dialogue involve two or more and both of them interact or communicate with each other. In this case, dialogue is divided in two forms, they are interpersonal and transactional. Interpersonal is exchange social relationship in communication. The speakers can be familiar with each other when the interlocutor produce conversations with more assumptions, implications, and other hidden meanings also the daily language. Whereas, when they are unfamiliar it can lead to misunderstanding when they are not speaking explicitly to assure effective comprehension.

\section{Aspects of Speaking Skill}

According to the brown (2001) there are four aspect of speaking skill, they are;

1. Pronunciation

According to Nunan (1999), pronunciation helps learners to identify the differences of meaning (based on stress, rhythm, and intonation) based on differences in individual sounds. Based on oxford dictionary, pronunciation is the way in which a language or a particular word or sound is spoken. From that statement, it can be concluded that pronunciation is a way to produce the words 
utterance clearly to help interlocutor identify differences of meaning based on rhythm, stress, and intonation.

2. Vocabulary

Based on oxford pocket dictionary, vocabulary is all the words that person knows and uses. Nunan (1998) explained that vocabulary is the lists of targets language words. Meanwhile, according to (Shepherd, 1987) there are two vocabularies: a receptive vocabulary and an expressive vocabulary. Receptive vocabulary is the words we know when we listen or read, and when we receive thoughts from others. Whereas expressive vocabulary is the words we use when we speak or write, that is when we express thoughts to others. Therefore, vocabulary is all the words that we receive from others and we used to speak or write.

3. Fluency

According to oxford pocket dictionary, fluency is a person able to speak a language easily and well. It usually refers to express oral language freely without interruption. It means that speakers express their oral language easily with normal speed without any interruption.

4. Grammar

Grammar is one of components in English language. It is systematic description of linguistic that describe of the rules for combining words into sentences. So, grammar is ordering of words arranged into a sentence to give a meaning.

5. Comprehension

Manser defines comprehension as the ability to understand something. In oxford pocket dictionary, comprehension means exercise that trains students to understand a language.

\section{Teaching Speaking}

Teaching speaking is a challenging responsibility as there are many problems related to every day practice. According to $\mathrm{Ur}$ (1999), some fundamental problems that appear in the speaking class include inhibition, complete silence, and low participation. Learners often feel afraid to say things in foreign language classroom. They are usually worried in making mistakes fearful of criticism or losing face, or simply shy of the attention that their speech attracts (Cahyono, 2010). In addition, learners often complain that they cannot think of anything to say; they have no motive to express themselves beyond the guilty feeling that they 


\section{JLIC}

should speak up. In the speaking class, only one participant can talk at a time if the students to be heard. In a large group this means that each participant will have only very little time to talk. The problem is compounded by the tendency that some learners are dominant, while others speak very little or not at all. In another case, there is a tendency for them to use mother tongue because it is easier.

The teacher is expected to design an activity that will be able to overcome those problems. Ur suggests four characteristics of successful speaking class. First, much of the time should be used for the activity involving the learners to talk. Second, classroom activity should not be dominated by talkative participants. All learners should get a chance to speak and contributions are distributed evenly. Third, learners are eager to speak because they are interested in the topic. Learners have something new to say about it, or because they want to contribute to achieve a task objective. Last, the learners express themselves in utterances that are relevant, easily comprehensible to each other, and of an acceptable level of language accuracy. One of the ways to realize a successful speaking class is through task based language learning. So, any four characteristics of successful speaking class, the students must have activity to improve their speaking skill in the class, the students must be diligent to improve sentences in any topics. The students should be having new creativities to achieve task objective, and the students must express their skill in level speaking. From the explanation above by designing the attractive activities, it is hoped that the successful speaking class can be reached.

\section{Inquiry-based Learning}

Inquiry based learning is an instructional practice where students explore content by posing, investigating, and answering question (Caswell and Labrie, 2017). Alberta (2004) argues that inquiry based learning is a process where students are involved in their learning, formulate questions, investigate widely, and then build new understanding, meaning and knowledge. That knowledge is new to students and may be used to answer a question, to develop a solution or to support a position or point of view. The knowledge is usually presented to others and may result in some short of action. 
Lane (2007) also agrees that inquiry-based learning method actively involves students in the exploration of the contents, issues, and questions surrounding a curricular area in the concept. The activities and assignment in an inquiry-based learning classroom can be designed such that students work individually or together to solve problems involving both in class work and fieldwork. The strategy is meant to be highly students-focused. Students-directed learning can vary depending on the level of the students in the course and their understanding.

Inquiry can be viewed as a process for answering questions and solving problems based on facts and observations (Rejeki, 2017). Based on this definition, the students ask questions and find the answers by themselves with some helps from the teacher, technology, and their learning community at the classroom level. Inquiry is a teaching method designed to teach students how to deal with questions and problems encountered in various important generic skill through a variety of learning experiences. Students need to be given appropriate guidance and feedback by teachers while and after the learning process.

\section{Components of Inquiry-based Learning}

According to Komalasari (2010), learning the methods of inquiry has 5 common components are as following:

1. Question

Learning usually begins with an opening question that provokes curiosity or admiration of students and the students will be a phenomenon. Students are given the opportunity to ask questions, which are intended as guidance to the core question to be solved by the students. Furthermore, teachers deliver the core questions or core problem to be solved by the students. So, the teachers give opportunity to ask some questions which intended to be solved by the students.

2. Students engagement

In the method of inquiry, the active involvement of students is a must, while the teacher's role is as a passive facilitator. The students do not plan to write answers to questions in the field or to answer the questions at the end of the chapter of a book, but prosecuted involved in creating a product that shows a students' understanding to the concepts which are being studied or in conducting an 


\section{JLIC}

investigation. However, students' engagement involved in creating a product being learned by the students

3. Cooperative interaction

Students are required to communicate, work in pairs or in groups, and discuss various ideas. In this case the student is not currently competing.The answer to the problems posed, the teachers can come in many forms, and probably the correct answer. So, cooperative interaction let the students to improve their skills from communication work pair or group and discuss about various ideas by correcting answers.

4. Performance evaluation

In answering the problem, usually the students are asked to create a product that can describe the knowledge about the problem being solved. This product can be a form of slide presentations, charts, posters, essays, and others. These products are to evaluate teachers. So, performance evaluation, students are asked to create the product and then the students describe the knowledge how to solve the problem.

5. Variety of resources

The students can use a variety of learning resources for example, textbooks, websites, television, video, posters, interviews with experts and others. So, varieties of resources more emphasize on students take them from wide range.

\section{Advantages of Inquiry-based Learning}

According to Roestiyah (2008), the inquiry method has advantages that can be stated as follows: 1) Inquiry method can form and develop the concepton students, so students can understand basic concept sand ideas better, 2) It assists on the use of memory and transfer to a new learning situation, 3) It encourages the students to think intuitively and formulate their own hypotheses, 4) It gives the individual's satisfaction to inquiry something, 5) The situation becomes more stimulating learning, 6) It can develop individual talents or skills, 7) It gives students the freedom to learn by using their own or group, 8) The students can avoid the students of the ways that traditionally, and 9) Inquiry method can give the students who learn that they can assimilate and accommodate Information.

Beside the advantages, there are some disadvantages of inquiry based learning. They are: 1) Required mental readiness for 
students, and 2) Requires an adjustment or adaptation from conventional method to inquiry learning method.

\section{METHODS}

Arikunto (2007) as quated by Wahono (2014:127) stated that classroom action research covered four activities as follows: planning, acting, observing, and reflecting.

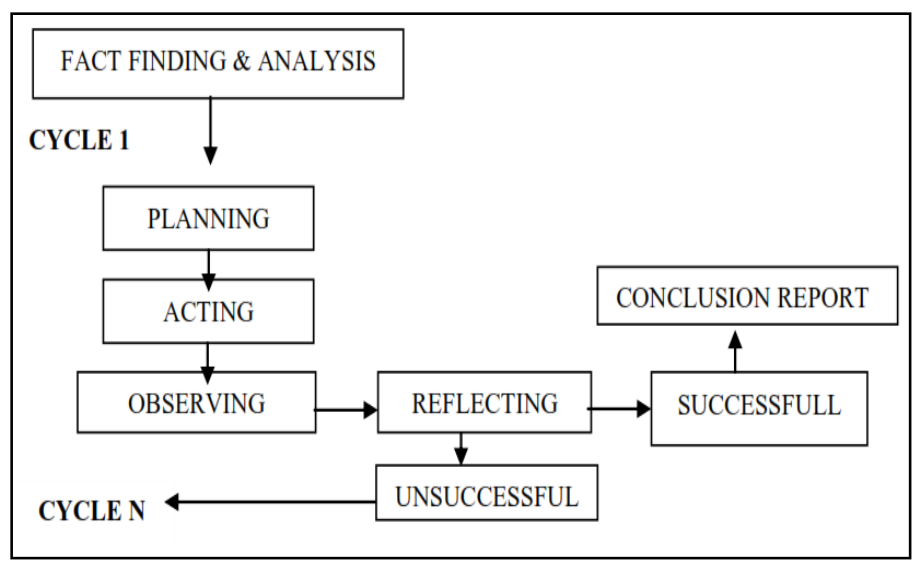

Figure 1. The Cycles of CAR

This study was conducted in vocational high school (SMK) PGRI 3 Tanggul of Jember. The researcher chose the tenth grade students of vocational high school because the researcher found that this class still had problems with speaking, and the students' speaking skill was categorized to be low.

To determine whether the cycle was successful or not, the researcher set up the criteria of success. The criteria of success in this study were when $60 \%$ of the number of students got a score of 70 (or above). If the criteria were fulfilled, it was considered that the research was successful. This study used some instruments namely speaking test, observation, and field notes.The instrument of data collection for speaking test was speaking scoring rubric; for observation was observation checklist; and for field notes were the collaborator's documents.

\section{RESULTS AND DISCUSSION}

The result of the research was presented as data description based on the test result. The data analysis result obtained through speaking test. Here was the table of pre-test and post-test scores: 


\section{JLIC}

Table 1. The students' Speaking skills score

\begin{tabular}{|c|c|c|}
\hline $\begin{array}{c}\text { Students' } \\
\text { number }\end{array}$ & Pre Test & Post Test \\
\hline $\mathrm{S}_{1}$ & 50 & 60 \\
\hline $\mathrm{S}_{2}$ & 70 & 80 \\
\hline $\mathrm{S}_{3}$ & 65 & 65 \\
\hline $\mathrm{S}_{4}$ & 60 & 65 \\
\hline $\mathrm{S}_{5}$ & 50 & 55 \\
\hline S6 & 60 & 65 \\
\hline$S_{7}$ & 50 & 55 \\
\hline S8 & 75 & 80 \\
\hline S9 & 80 & 85 \\
\hline Sio & 65 & 65 \\
\hline S11 & 65 & 70 \\
\hline S12 & 80 & 85 \\
\hline $\mathrm{S}_{13}$ & 80 & 85 \\
\hline S14 & 65 & 70 \\
\hline S15 & 75 & 80 \\
\hline S16 & 80 & 85 \\
\hline $\mathrm{S}_{17}$ & 80 & 85 \\
\hline S18 & 65 & 70 \\
\hline S19 & 65 & 70 \\
\hline $\mathrm{S}_{20}$ & 80 & 85 \\
\hline$S_{21}$ & 70 & 75 \\
\hline$S_{22}$ & 50 & 60 \\
\hline $\mathrm{S} 23$ & 50 & 60 \\
\hline S24 & 70 & 80 \\
\hline S25 & 65 & 70 \\
\hline Total score & $\Sigma \mathrm{X}_{1}=1.665$ & $\Sigma \mathrm{X}_{2}=1.805$ \\
\hline Mean & 66.6 & 72.2 \\
\hline
\end{tabular}

Both pre test and post test involved 25 students. The students' total score in pre test was 1.665. Meanwhile the mean of the score was 66.6. The students' total score in post test was 1.805 . Meanwhile the mean of the score was 72.2. From the data that the total score or the mean of post tes was higher than pre test one. 


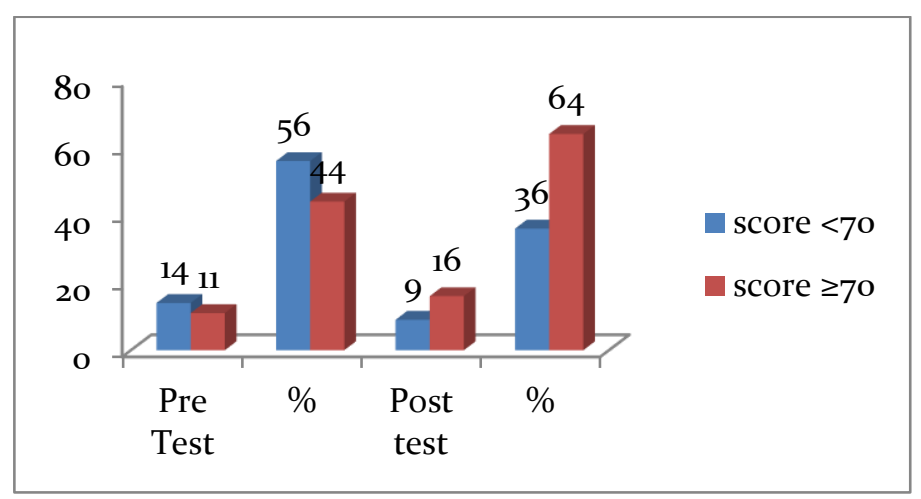

Figure 2. The Recapitulation of Students' Score within pre and post-test

The number of the students was 25 students. The students' score that were gotten before conducting the inquiry-based learning model could be described as follows; a) the students who got score less than 70 were 14 students or $56 \%$, the students who got score more or equal than 70 were 11 students or $14 \%$. Meanwhile The students' score that were gotten after conducting the model could be described as follows; a) the students who got score less than 70 were 9 students or $36 \%$, the students who got score more or equal than 70 were 11 students or $64 \%$.

The teacher gave questions to students and provided opportunities for students to ask questions about material that has not been understood. With these activities, the teacher's role is more likely to be a facilitator. The opportunity given to students was an activity to build students' concepts to be able to express their ideas freely. Providing opportunities for students was a form of learning process that involved students as a characteristic of student-centered learning._Besides that, learning activities opened up opportunities for students to build communication and interaction between fellow learning communities in the classroom. Nunan (2003) states that the teachers should provide an opportunity for students to talk by using group work and pair work and limit the teachers talk. It is important for the teachers to pay attention on giving many opportunities to the students to talk much than them.

The speaking learning process involved the students to active in speaking. The students spoke and interacted with group or classmate in classroom by working together. Answering some questions was activities were done by them to engage in 


\section{JLIC}

communication. Besides they expressed their ideas without any doubt. As Komalasari (2010) stated that cooperative interaction let the students to improve their skills from communication work pair or group and discuss about various ideas by correcting answers. Chappell (2014: 30) states that small group work can contribute to classroom second language learning. Group work in the interactive second language classroom develops oral fluency and accuracy.

Through the learning activities in Inquiry-Based Learning, the teacher emphasized the use of language interactively where integrated activities occurred (Fatkhriyah, 2019). The speaking learning process involved the students to active in speaking. The students spoke and interacted with group or classmate in classroom by working together. Answering some questions was activities were done by them to engage in communication. Besides they expressed their ideas without any doubt. As Koemalasari (2010) stated that cooperative interaction let the students to improve their skills from communication work pair or group and discuss about various ideas by correcting answers.

\section{CONCLUSION}

This study concludes that the use of inquiry-based learning improved speaking skill at the tenth grade students' of SMK PGRI 3 Tanggul Jember. The English teacher can use inquiry based learning for teaching and learning speaking. It has a big contribution in learning process. The students will be more active. They solve their problem by looking for the information not only from the book but also form outside the book. It helps students to avoid getting bored in the classroom. 
Suparwoto Sapto Wahono,

Ira Hamida Nurul Zahro

\section{REFERENCES}

Alberta, (2004). "Focus On Inquiry: A Teaher's Guide To Implementing Inquiry-Based Learning". Canada: Alberta Learning, Copyright.

Brown. H. Douglas (2003). "Teaching by Principles: An Interactive Approach to Language Pedagogy". New York: Longman.

Cahyono. Bambang Yudi (2010). "The Teaching Of English Language Skills And English Language Component “. Malang: State University Of Malang Press.

Caswell. Caroline J. Labrie, Derek. (2017). "Inquiry Based Learning From Learners Point Of View: A Teacher Candidate's Success Story". Journal Of Humanistic Mathematics, Vol 7, 125

Fatkhriyah. RY. (2019). Inquiry-Based Learning: An Attempt to Enhance Students' Speaking Performance. Jurnal Pendidikan, Vol. 4, No. 7, p. 912-922

Harmer. Jeremy, (2001). The Practice of English Language Teaching England: Pearson Education Limited.

Hussain. Shafaat (2017). Teaching Speaking Skill In Communication Classroom. International Journal Of Media, Journalism And Communication, Vol 3, ISSN 2454-9479

Kinsvatter. Richard (1996). Dynamics Of Effective Teaching. New York: Longman Publisher.

Koemalasari. Kokom. (2010). "Pebelajaran Konstektual Konsep Dan Aplikasi. Bandung: PT Refika Aditama.

Nunan. David (1999). "Second Language Teaching E Learning". Boston: Heinle \& Heinle Publisher.

Oxford University Press, Oxford Learner's Pocket Dictionary. New York: Oxford University Press.

Rejeki. Sri. (2017). "Inquiry Based Language Learning (Ibll): Theoretical And Practical Views In English Classroom". English Franca, Vol 1, No 2, E-ISSN 2580-3689.

Richards. Jack C., A. Willy (2001) Methodology in Language Teaching, New York: Cambridge University Press.

Roestiyah. (2008). "Strategi Belajar Mengajar". Jakarta: Pt Rineka Cipta.

Shepherd. James F.(1987). “Collehe Vocabulary Skills”. New York: Houghton Miffin Company.

Ur. Penny. (1991). “ A Course In Language Teaching”. Cambridge:

Cambride University Press. 


\section{JLIC}

Wahono. Suparwoto Sapto, Qodriah. Ulfa Khodijatul. (2019). Improving Students Writing Skill Using English Movie with Subtitle. International Journal of Scientific and Research Publications. Vol. 9 (12): 593-599.

Wahono. Suparwoto Sapto. (2014). Using $\mathrm{PQ}_{4} \mathrm{R}$ to Increase The Students' Reading Comprehension at Al-Bidayah Islamic Boarding School Jember. Fenomena, Vol. 13, No. 2. p. 127

Wahono. Suparwoto Sapto. (2018). The role of language lectures in developing students' attitude and speaking skill of English department Students at IAIN Jember. Jurnal Turats Kajian Ilmu Penddikan Bahasa dan Peradaban. Vol.10:98. 